\title{
MICROSTRUCTURAL ASPECTS OF LONG-TERM AGEING OF MARTENSITIC 9\% Cr STEEL WITH AND WITHOUT BORON ADDITION
}

\author{
MIKROSTRUKTURALNE ASPEKTY DŁUGOTRWAŁEGO STARZENIA \\ STALI MARTENZYTYCZNYCH TYPU 9\% Cr Z DODATKIEM \\ I BEZ DODATKU BORU
}

The study covered 9\% Cr martensitic steels - X10CrMoVNb9-1 (P91) and X13CrMoCoVNbNB9-2-1 (PB2) after long-term ageing at the temperature of $62 O^{\circ} \mathrm{C}$ and soaking time up to 50,000 hours. The microstructural investigations of the tested steels were carried out using a TITAN 80-300 transmission electron microscope. The analysis of the changes in the microstructure included the identification of precipitates and computer image analysis: the measurement of dislocation density and mean diameter of the precipitates. The tests showed that the analysed steels still retained the lath martensitic microstructure, but also the processes of matrix softening were observed. The microstructure of the examined steels also showed numerous precipitates with various morphologies. The micro-addition of boron in the PB2 steel, compared with the P91 steel, influenced the retardation of the microstructure degradation processes through the limitation of the growth of $M_{23} C_{6}$ precipitates and Laves phase. This resulted in a slowdown in the processes of recovery and polygonisation of the matrix of the tested steel.

Keywords: martensitic steel, PB2 steel, P91 steel, degradation of microstructure
Badaniu poddano martenzytyczne stale typu $9 \% \mathrm{Cr}-\mathrm{X} 10 \mathrm{Cr}$ MoVNb9-1 (P91) oraz X13CrMoCoVNbNB9-2-1 (PB2) po dtugotrwatym starzeniu w temperaturze $620^{\circ} \mathrm{C} i$ czasie wygrzewania do 50 ooo godzin. Badania mikrostrukturalne badanych stali przeprowadzono za pomoca transmisyjnego mikroskopu elektronowego TITAN 80-300. Analiza zmian w mikrostrukturze obejmowata identyfikację wydzieleń oraz komputerowa analize obrazu: pomiar gęstości dyslokacji i średniej średnicy wydzielen. Przeprowadzone badania wykazaty, że analizowane stale posiadaty nadal zachowana listwowa mikrostrukture martenzytyczna, ale takize obserwowano procesy mięknięcia osnowy. W mikrostrukturze badanych stali widoczne były rówonież liczne roydzielenia o różnej morfologii. Mikrododatek boru w stali PB2 w porówonaniu do stali P91 wptyną na spowolnienie procesów degradacji mikrostruktury poprzez ograniczenie wzrostu roydzielen $M_{23} C_{6}$ i fazy Lavesa. Wptynęto to na spowolnienie procesów zdrowienia i poligonizacji osnowy badanej stali.

Stowa kluczowe: stale martenzytyczna, stal PB2, stal P91, degradacja mikrostruktury

\section{INTRODUCTION}

In high-chromium $9-12 \%$ Cr steels, the basic precipitates are chromium-rich $\mathrm{M}_{23} \mathrm{C}_{6}$ carbides, which play an important role in these steels as a stabilising factor for the martensitic lath microstructure. Previous experiments in the use of modern martensitic 9\% Cr steels in the power industry showed that the main mechanisms of degradation of materials are processes of coagulation of $\mathrm{M}_{23} \mathrm{C}_{6}$ carbides and the release and increase of the Laves phase [1-3]. The increase in the size of $\mathrm{M}_{23} \mathrm{C}_{6}$ carbides and Laves phase precipitates during operation results not only in the limitation of their effect on precipitation strengthening, but also leads to the formation of a continuous network on grain boundaries. Numerous precipitates on grain/lath boundaries not only increase the brittleness of the steel, but also change

Corresponding Author: grzegorz.golanski@wip.pcz.pl the cracking mechanism from ductile to brittle. In addition, the diffusion of atoms of substitutional elements (chromium, molybdenum, tungsten) into the released Laves phase and/or $\mathrm{M}_{23} \mathrm{C}_{6}$ carbides contributes to the steel's tendency to recover and polygonise the matrix and reduce resistance to oxidation [2-6]. The introduction of the micro-addition of boron into martensitic steels is kind of an antidote for the tendency of $\mathrm{M}_{23} \mathrm{C}_{6}$ and Laves phase precipitates to coagulate. Boron partially substitutes carbon atoms in the $\mathrm{M}_{23} \mathrm{C}_{6}$ carbide, forming more stable $\mathrm{M}_{23}(\mathrm{C}, \mathrm{B})_{6}$ carboborides. During use, these precipitates tend to coagulate and are characterised by greater dispersion. A similar, positive effect of boron was observed on the retardation of the process of Laves phase precipitation and increase in its stability $[2,5,7]$.

The aim of the study was to analyse the influence of longterm ageing on changes in the microstructure of $9 \% \mathrm{Cr}$ steels - X10CrMoVNbN9-1 (P91) and X13CrMoCoVNbNB9-2-1 (PB2). 


\section{MATERIAL AND METHODOLOGY}

The studied material consisted of samples taken from tube sections of the following steels: X10CrMoVNb9-1 (P91) and X13CrMoCoVNbNB9-2-1 (PB2) with the following dimensions: $160 \times 16.8 \mathrm{~mm}$ and $219 \times 32 \mathrm{~mm}$. The chemical composition of the tested steels, determined using a SpectroLab K2 spark spectrometer, is presented in Table 1. The tested steels were subjected to ageing at $620^{\circ} \mathrm{C}$ and annealing time of up to 50,000 hours.

The microstructural investigations were carried out with a TITAN 80-300 transmission electron microscope (TEM) with a $220 \mathrm{kV}$ accelerating voltage. The observation of the microstructure was carried out for the delivered steel and after 50,000 hours of ageing at $620^{\circ} \mathrm{C}$.

The microstructural studies using a transmission electron microscope were carried out using thin films. The identification of precipitates was carried out using selective electron diffraction. The measurement of the density of free dislocations within the sub-grains and the average width of martensite laths was carried out on microstructure images. The quantitative analysis of precipitates was carried out using computer image analysis with the Image ProPlus program.

\section{TEST RESULTS AND OVERVIEW}

\subsection{MICROSTRUCTURE OF THE DELIVERED STEEL}

The occurrence of lath structure of tempered martensite with a sub-grain structure with a high density of free dislocations inside the sub-grains and numerous precipitates was observed in the provided steels (Fig. 1). The microstructure of these steels also reveals the occurrence of single areas of polygonised ferrite. The estimated average free dislocation density in steels P91 and PB2 was similar in the delivery condition and amounted to $1.21 \cdot 10^{14} \mathrm{~m}^{-2}$ and $1.23 \cdot 10^{14} \mathrm{~m}^{-2}$, respectively. The following three precipitation types were observed in the delivered steels: $\mathrm{M}_{23} \mathrm{C}_{6}$ carbides and MC (MX) carbides and carbonitrides (Fig. 2, 3). $\mathrm{M}_{23} \mathrm{C}_{6}$ carbides were distributed in the tested steels on former austenite grain boundaries and on martensite sub-grain/lath boundaries.

After quenching and tempering, $\mathrm{M}_{23} \mathrm{C}_{6}$ carbides in 9-12\% $\mathrm{Cr}$ high-chromium steels are the predominant precipitate and constitute approx. 90\% of all precipitates [8]. $\mathrm{M}_{23} \mathrm{C}_{6}$ carbides play a significant role in $9-12 \% \mathrm{Cr}$ martensitic steels, because they stabilise the sub-grain microstructure and delay the processes of matrix softening (processes of polygonisation and recrystallisation of the matrix). The average diameter of $\mathrm{M}_{23} \mathrm{C}_{6}$ precipitates in the delivered steel P91 was $106 \mathrm{~nm}$, while in the case of steel PB2 it was smaller and amounted to $76 \mathrm{~nm}$. The difference in the size of $\mathrm{M}_{23} \mathrm{C}_{6}$ precipitates in the delivered steel may result from both the heat treatment parameters (temperature and tempering time) and the stabilisation of these precipitates in the PB2 steel with boron. In the case of MX precipitates, two of their morphologies were observed: spherical, rich in niobium $\mathrm{NbC}$ and lamellar, rich in vanadium - VX precipitates (nitrides/carbonitrides). $\mathrm{NbC}$ particles are released in the final coagulation phase, hence their role is essentially limited to inhibiting the austenite grain growth during austenitising, increasing the ductility and strength of $9-12 \% \mathrm{Cr}$ steel [9, 10]. On the other hand, vanadium-rich MX precipitates are secondary precipitates released during tempering [10].

Table 1. Chemical composition of tested steels, wt \%

Tabela 1. Skład chemiczny badanych stali, \% masy

\begin{tabular}{|c|c|c|c|c|c|c|c|c|c|c|c|c|}
\hline Steel & C & Si & Mn & Cr & Mo & V & Nb & N & Co & P & S & B \\
\hline P91 & 0.11 & 0.42 & 0.51 & 9.12 & 0.93 & 0.22 & 0.077 & 0.05 & - & 0.018 & 0.0040 & - \\
\hline PB2 & 0.14 & 0.11 & 0.34 & 9.42 & 1.55 & 0.19 & 0.057 & 0.04 & 1.38 & 0.011 & 0.0008 & 0.008 \\
\hline
\end{tabular}
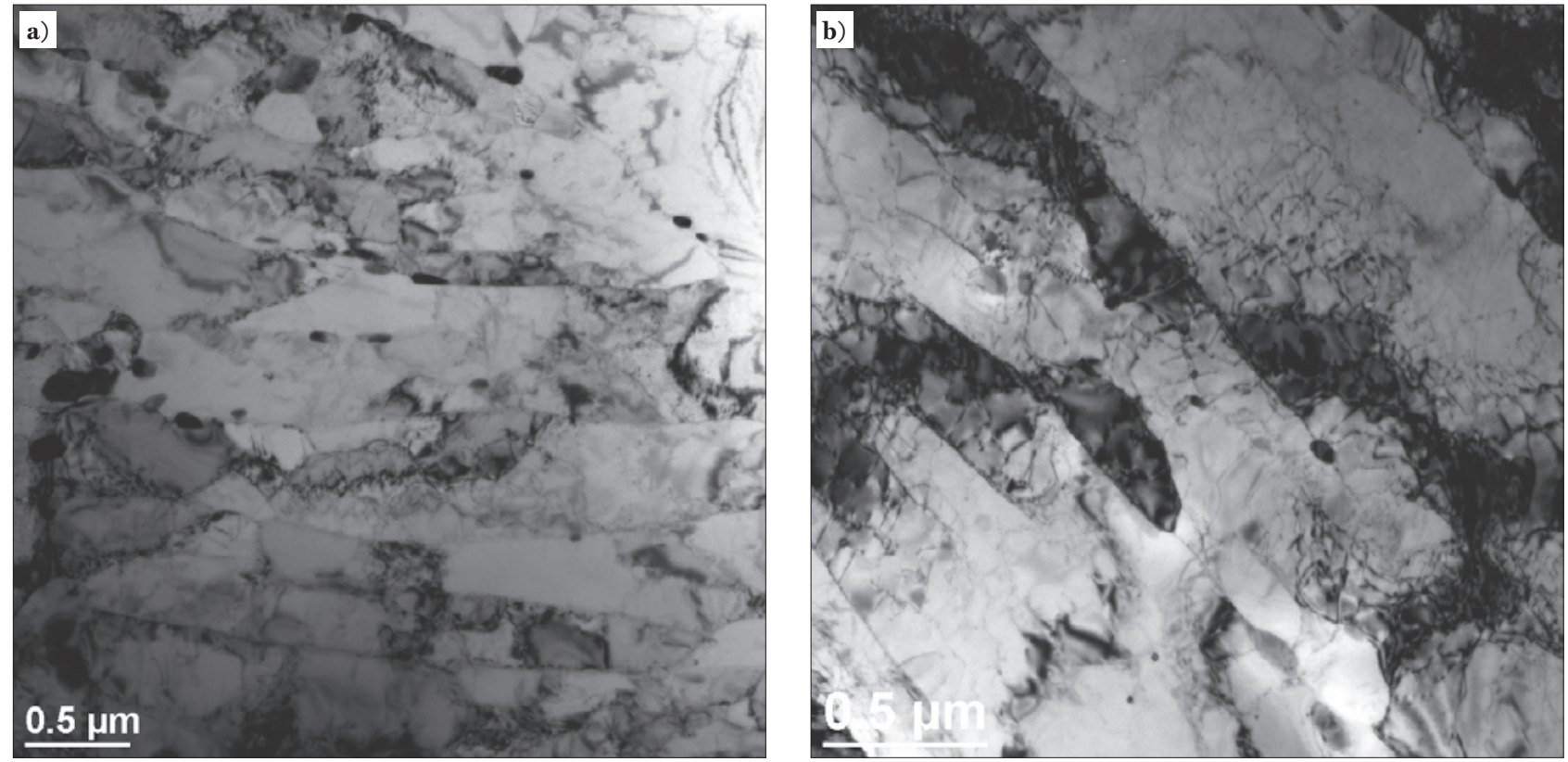

Fig. 1. Microstructure of the delivered steels subjected to the study: a) P91; b) PB2, TEM

Rys. 1. Mikrostruktura badanych stali w stanie dostawy: a) P91; b) PB2, TEM 

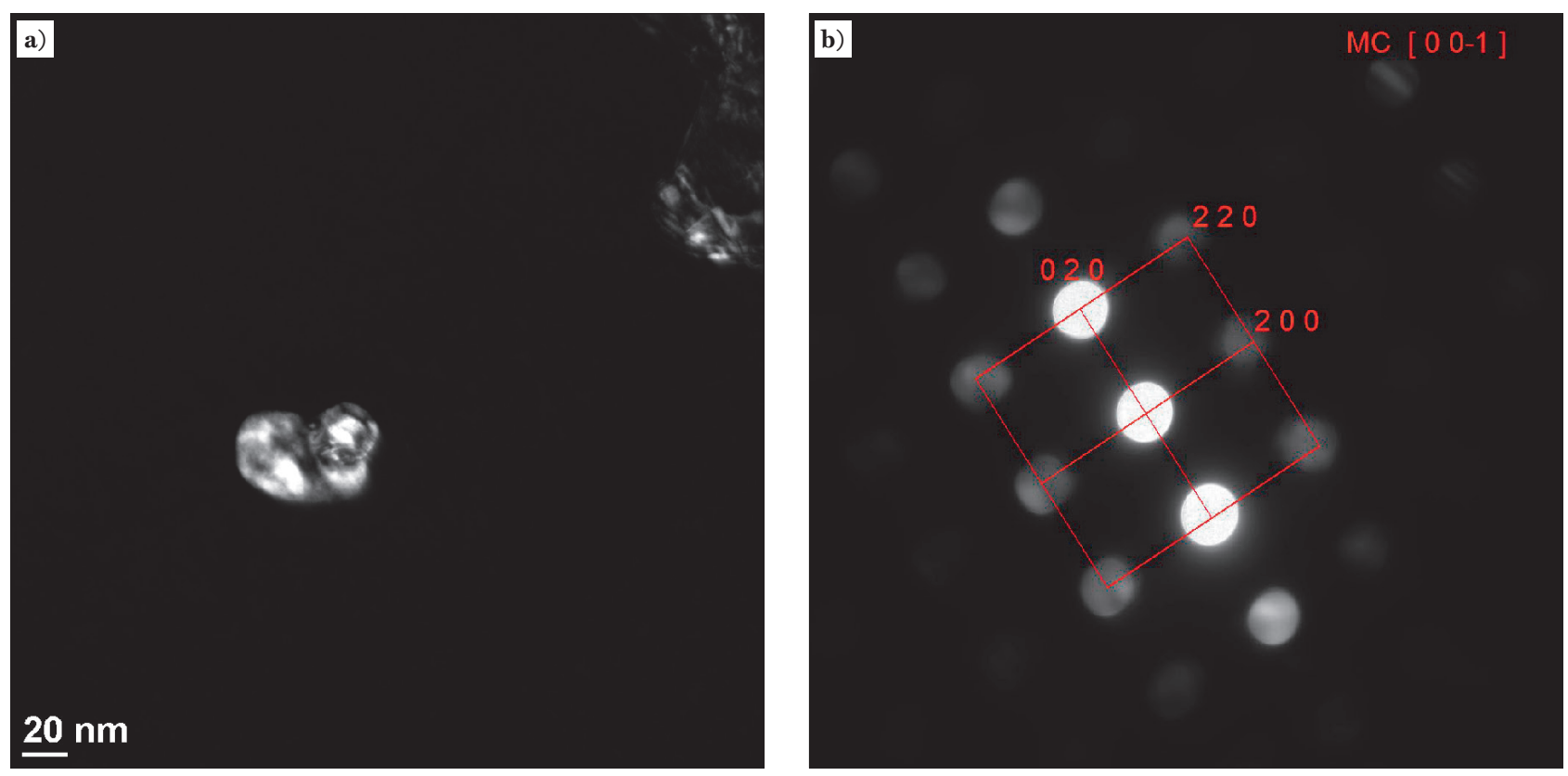

Fig. 2. MN precipitate in the microstructure of the delivered P91 steel: a) dark field; b) solved electron diffractogram Rys. 2. Wydzielenie MN w mikrostrukturze stali P91 w stanie dostawy: a) ciemne pole; b) rozwiązany dyfraktogram elektronowy
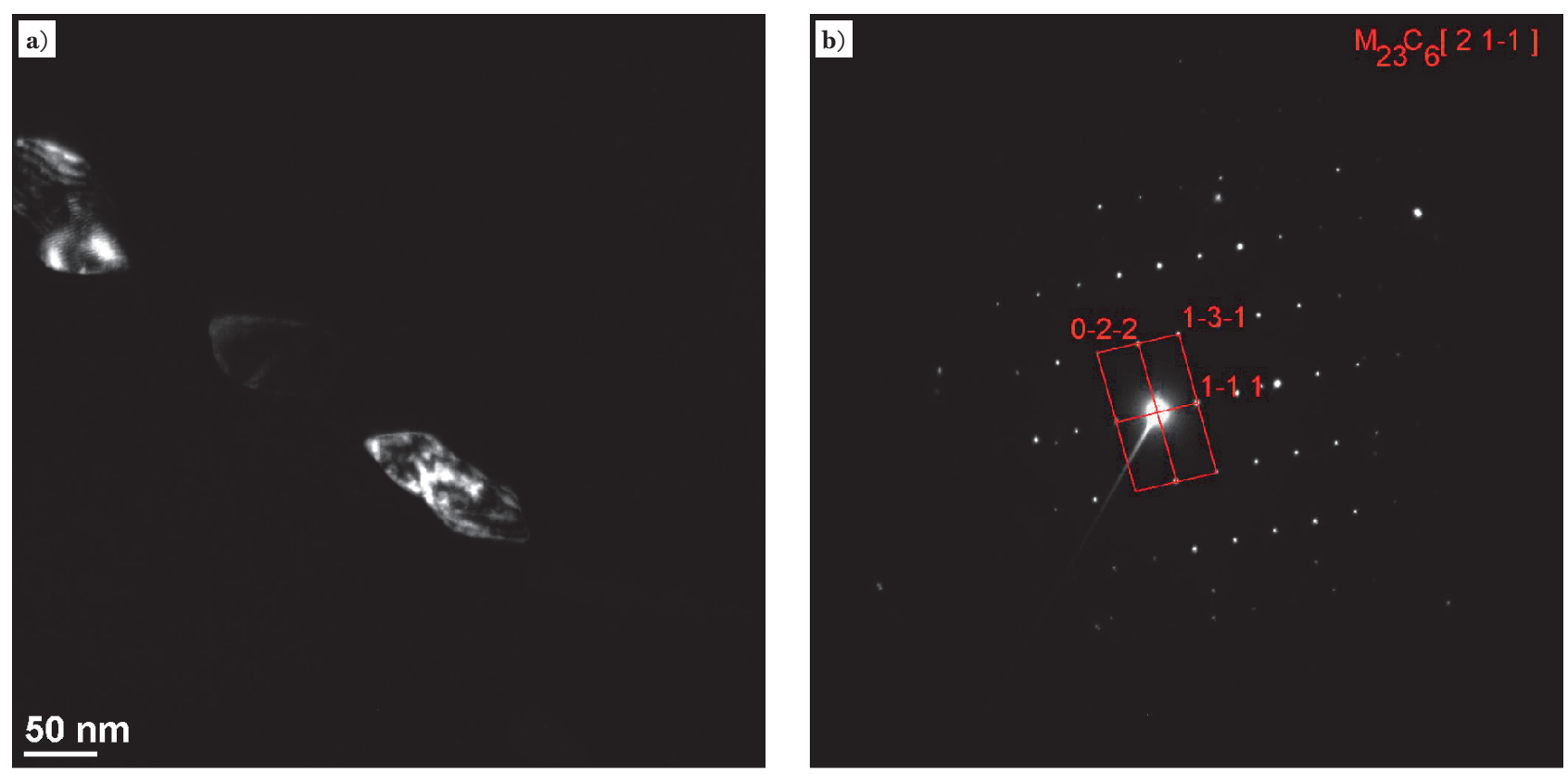

Fig. 3. $M_{23} C_{6}$ carbide in the microstructure of the delivered P91 steel: a) dark field; b) solved electron diffractogram

Rys. 3. Węglik $M_{23} C_{6}$ w mikrostrukturze stali P91 w stanie dostawy: a) ciemne pole; b) rozwiązany dyfraktogram elektronowy

According to Orowan mechanism, creep rate depends on the rate of dislocation movement, which in turn depends on the dispersion of precipitates. Fine-dispersive precipitates are an effective barrier limiting the free movement of dislocations. The fine-dispersive MX precipitates were observed inside the sub-grains, mainly on dislocations. The average diameter of MX precipitates in the delivered steel P91 was $32.4 \mathrm{~nm}$, while in the case of steel PB2 $-25.7 \mathrm{~nm}$.

\subsection{MICROSTRUCTURE OF STEEL P91 AND PB2 AFTER LONG-TERM AGEING}

The delivered quenched and tempered martensitic 9\% $\mathrm{Cr}$ steels have a metastable microstructure that undergoes a gradual evolution under the influence of temperature and time. The rate of change in the microstructure of heatresistant steels depends mainly on the operating/experiment temperature.

After long-term ageing, a partly preserved lath system of martensitic microstructure was observed in the microstructure of the investigated steels, and areas of polygonised ferrite were also visible (Fig. 4). The ageing of the investigated steels contributed to changes in their dislocative microstructure. The average density of free dislocations in steel P91 after $50000 \mathrm{~h}$ of ageing at $620^{\circ} \mathrm{C}$ was $5.65 \cdot 10^{12} \mathrm{~m}^{-2}$, while in steel PB2 $8.61 \cdot 10^{12} \mathrm{~m}^{-2}$. The estimated decrease in the density of dislocations in the studied steels was related to the processes of recovery and polygonisation of the matrix, 

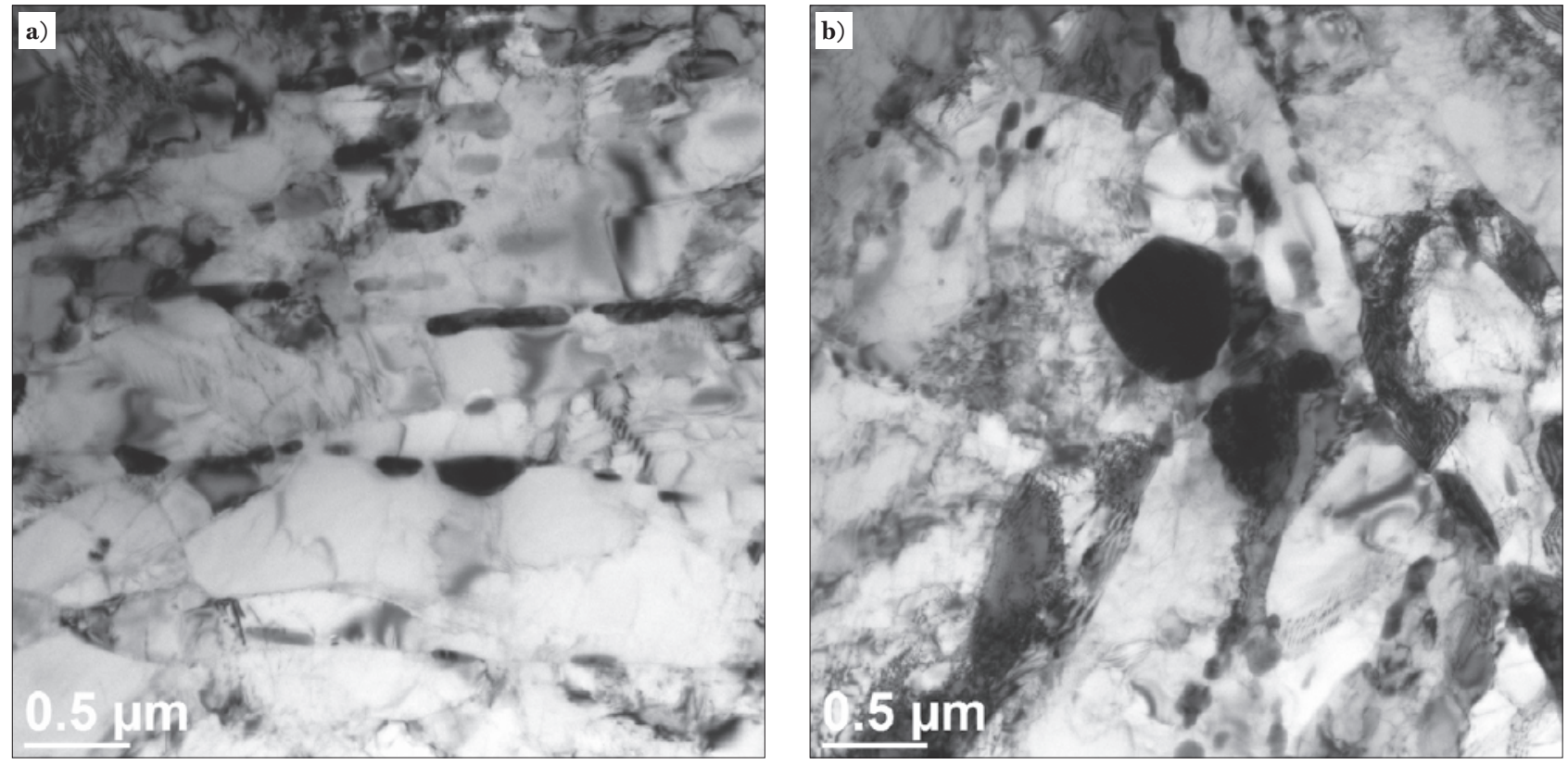

Fig. 4. Microstructure of the tested steels after ageing: a) P91; b) PB2, TEM Rys. 4. Mikrostruktura badanych stali po starzeniu: a) P91; b) PB2, TEM

occurring through the rearrangement of the dislocations to low-energy configurations, their elimination and annihilation within boundaries. Despite the processes of softening of the matrix in the investigated steels after ageing, the impact of dislocation inside the sub-grains with fine-dispersed precipitates was still visible.

The long-term ageing of the examined steels, apart from the evolution of the dislocation microstructure, also contributed to the change in the morphology and the type of precipitates. Similarly to the delivery condition, both $\mathrm{M}_{23} \mathrm{C}_{6}$ carbides and MX precipitates were observed in their microstructure (Fig. 5, 6). These precipitates were revealed along former austenite grain boundaries, inside and on sub-grain boundaries. The number of precipitates on grain boundaries of former austenite and on lath boundaries was so large that they formed a continuous network of precipitates (Fig. 4). MX precipitates were also observed inside the sub-grains. The average diameter of $\mathrm{M}_{23} \mathrm{C}_{6}$ carbides after 50,000 hours of ageing was approx. $158 \mathrm{~nm}$ - steel P91 and $108 \mathrm{~nm}$ - steel PB2 respectively, while for MX precipitates: $33 \mathrm{~nm}$ for steel P91 and $30 \mathrm{~nm}$ in steel PB2. The increase in the size of $\mathrm{M}_{23} \mathrm{C}_{6}$ carbides, assuming their constant volume fraction, in accordance with Ostwald's law, leads to a reduction in their number and contributes to their inhomogeneous distribution. This leads to a reduction in the effect of $\mathrm{M}_{23} \mathrm{C}_{6}$ carbides as an effective factor stabilising and controlling the
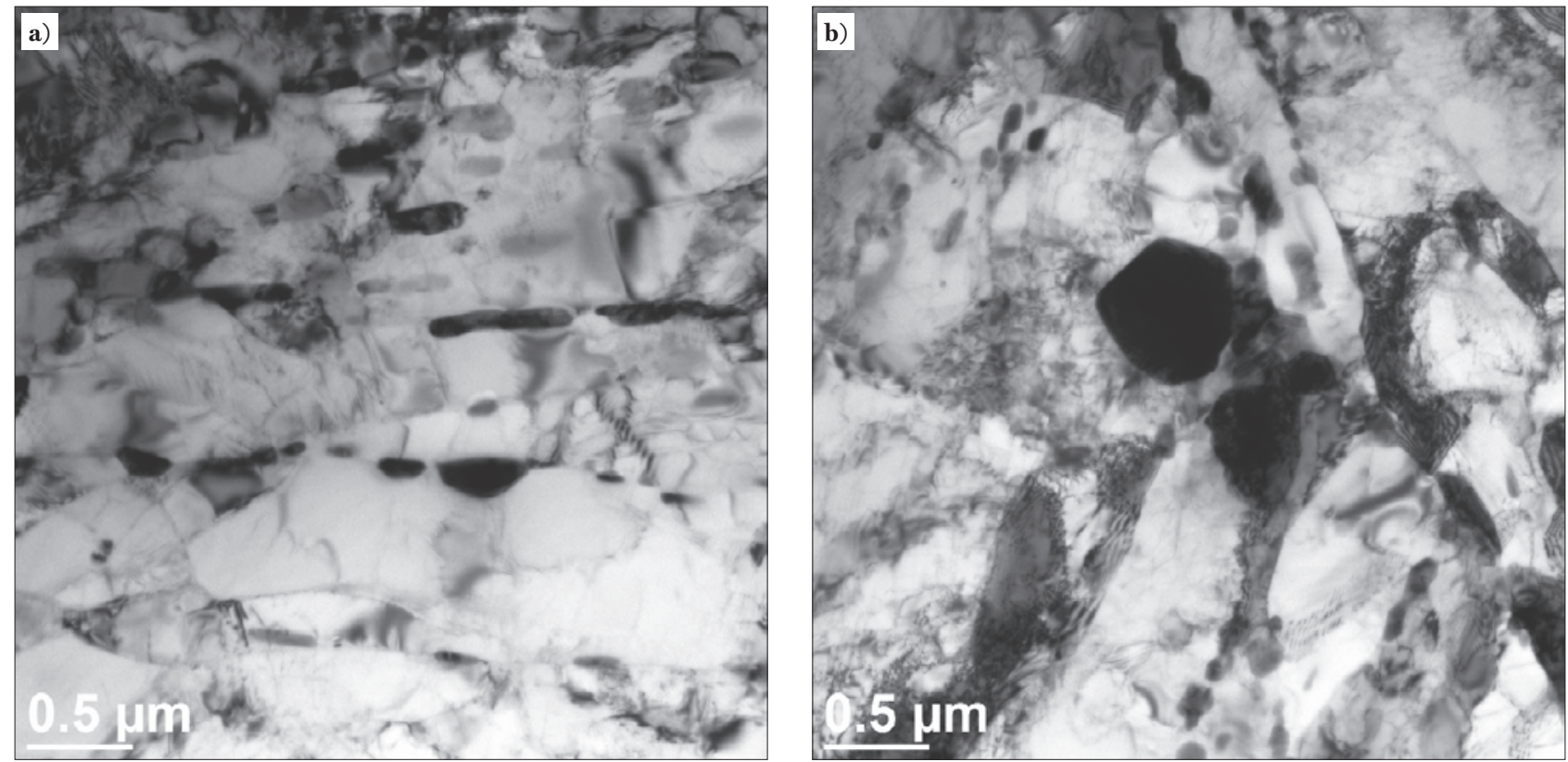

Fig. 5. $\mathrm{M}_{23} \mathrm{C}_{6}$ carbide precipitate in the microstructure of the P91 steel after 50,000 hours of ageing: a) bright field; b) solved electron diffractogram

Rys. 5. Wydzielenie weglika $M_{23} C_{6}$ w mikrostrukturze stali P91 po 50000 godzin starzenia: a) jasne pole; b) rozwiązany dyfraktogram elektronowy 

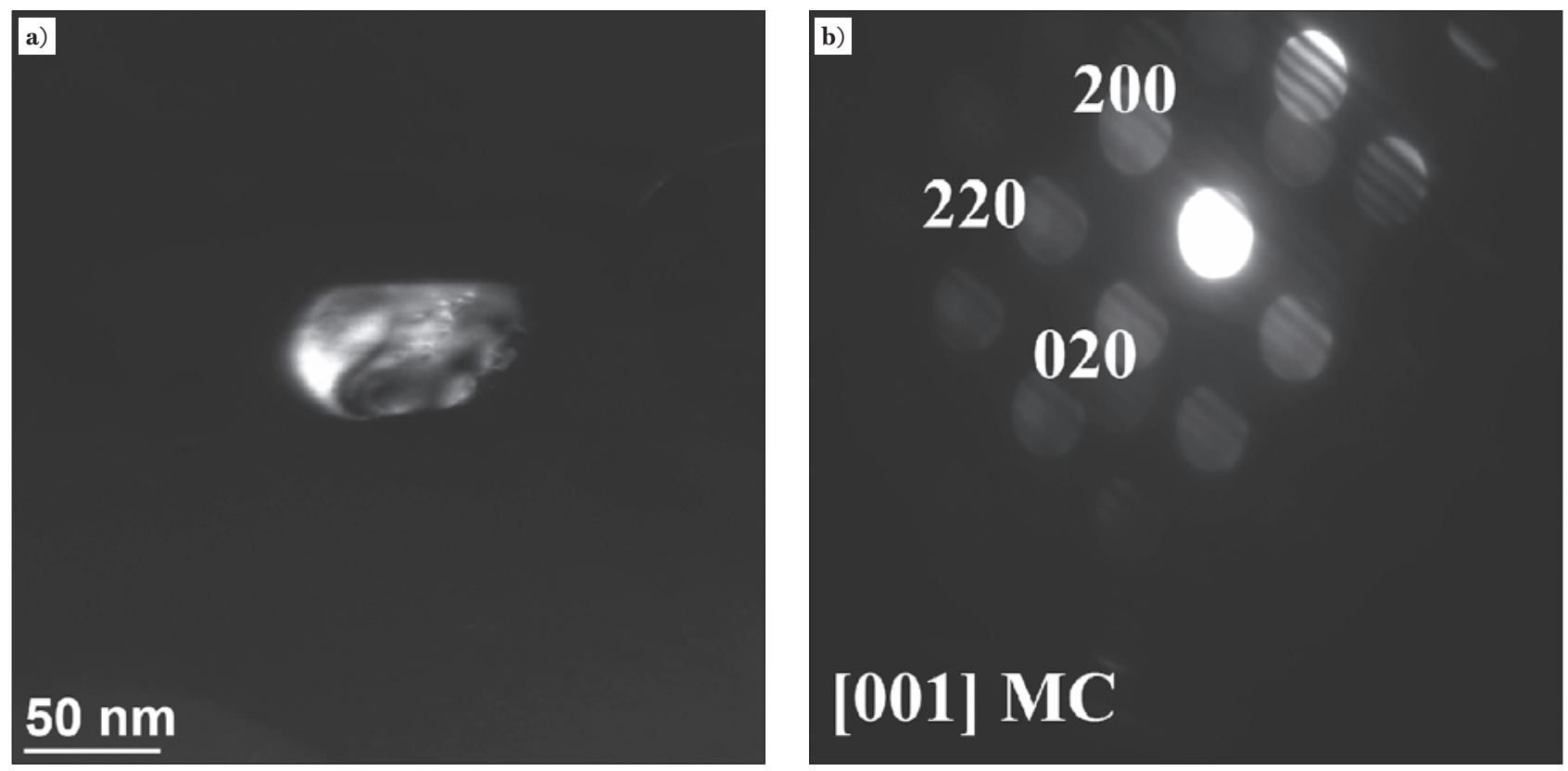

Fig. 6. MC carbide precipitate in the microstructure of the PB2 steel after 50,000 hours of ageing: a) dark field; b) solved electron diffractogram

Rys. 6. Wydzielenie węglika MC w mikrostrukturze stali PB2 po 50 ooo godzin starzenia: a) ciemne pole; b) rozwiązany dyfraktogram elektronowy

increase in the size of sub-grains. The increase in the size of sub-boundaries takes place as a result of migration or coalescence of sub-boundaries and usually occurs through the Y mechanism [11].

The small increase in the size of $\mathrm{M}_{23} \mathrm{C}_{6}$ carbides in the PB2 steel, compared to steel P91, indicates the positive effect of boron micro-addition on the stability of these precipitates. Boron segregates to the boundaries of former austenite grains and other defects of the microstructure reducing their energy, hence boron atoms can also segregate to the surface of the $\mathrm{M}_{23} \mathrm{C}_{6}$ carbide/matrix separation, contributing to the reduction of its energy, which results in a decrease in coagulation rates [7]. Therefore, it can be assumed that boron

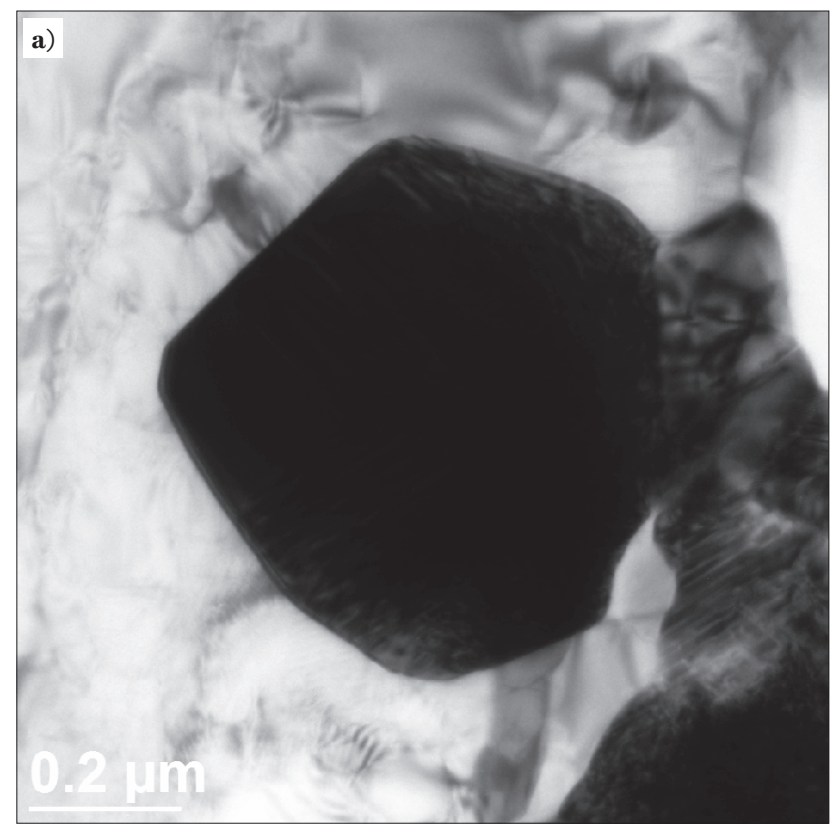

unbound in the precipitates, but dissolved in the matrix can significantly affect the stabilisation of the microstructure. According to $[7,12]$, in addition to boron bound in the precipitates, a few ppm of the dissolved element remain in the ferrite.

The comparable average diameter of MX precipitates in the tested steels proves their high stability during long-term, isothermal annealing. Stable MX precipitates cause a very slow decrease in precipitation strengthening and maintaining high strength properties for a relatively long duration.

In the tested steels, apart from $\mathrm{M}_{23} \mathrm{C}_{6}$ and $\mathrm{MX}$ particles, two types of secondary precipitates were also revealed: precipitates of the Laves phase (Fig. 7, 8) and the complex

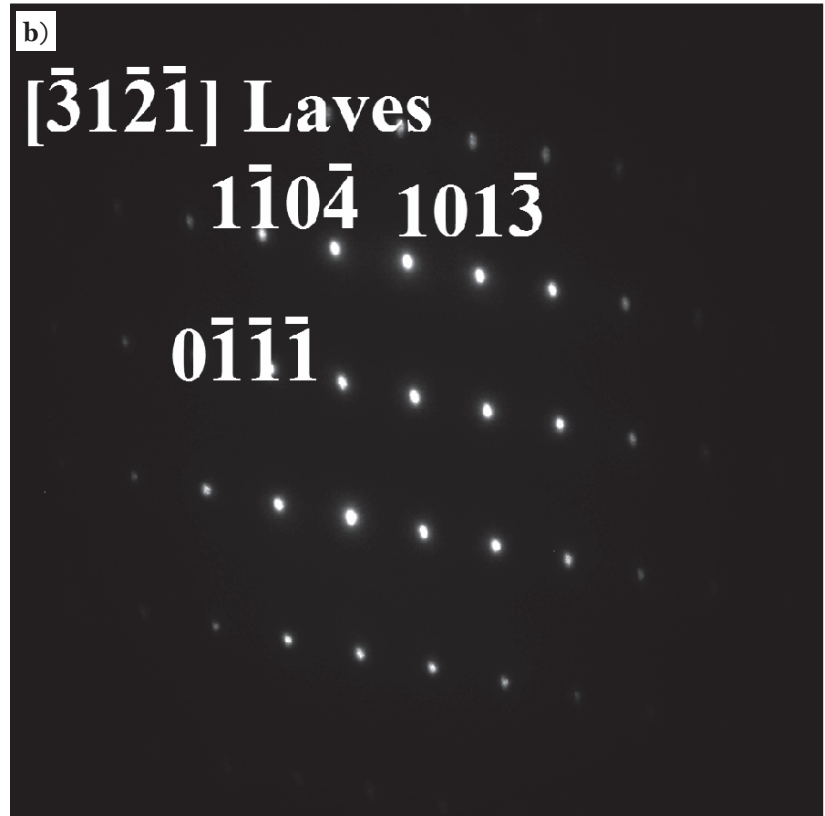

Fig. 7. Laves phase precipitate in the microstructure of the P91 steel after 50,000 hours of ageing: a) bright field; b) solved diffractogram Rys. 7. Wydzielenie fazy Lavesa w mikrostrukturze stali P91 po 50000 godzin starzenia: a) jasne pole; b) rozwiązany dyfraktogram 

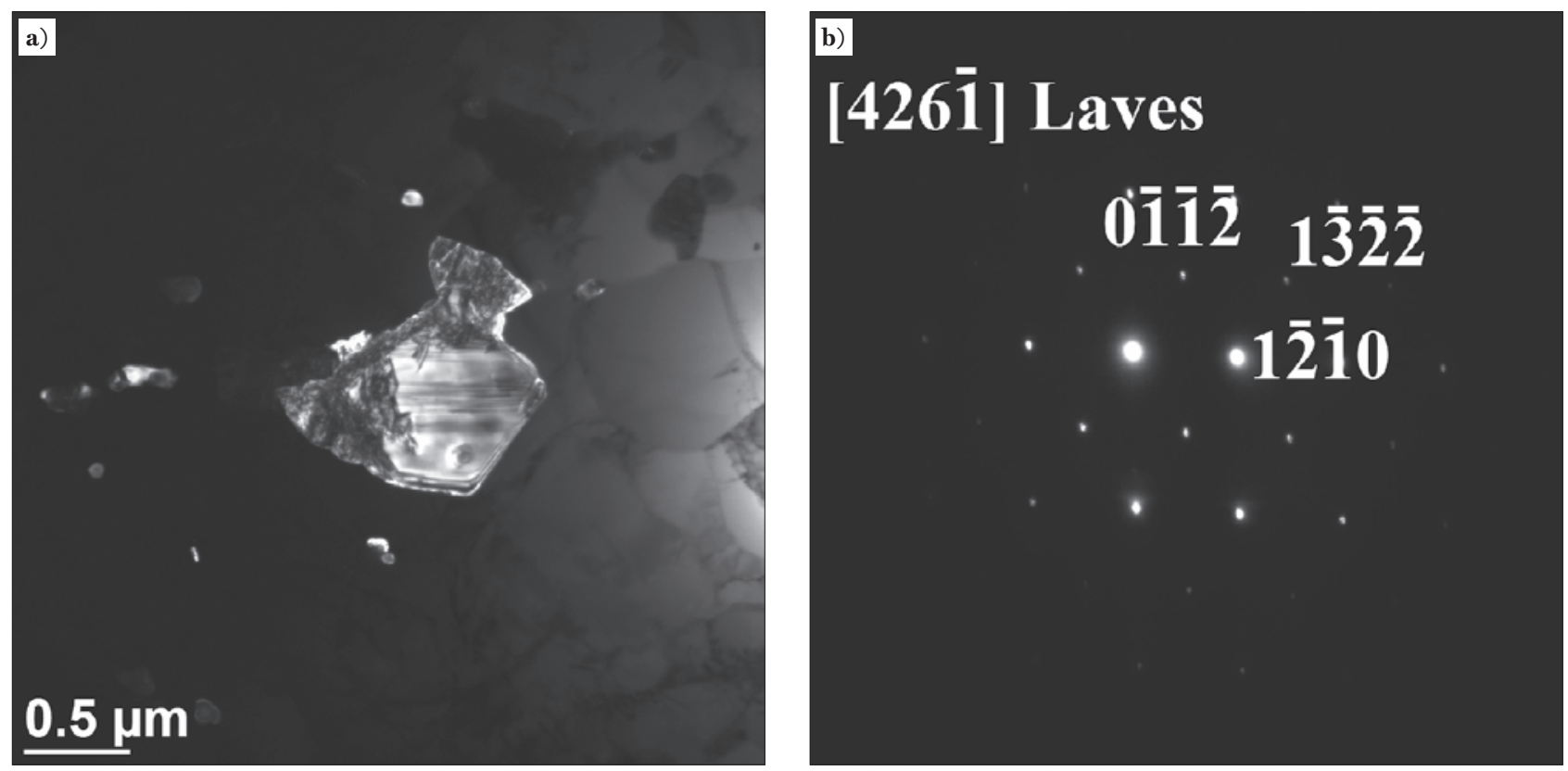

Fig. 8. Laves phase precipitate in the microstructure of the PB2 steel after 50,000 hours of ageing: a) dark field; b) solved diffractogram Rys. 8. Wydzielenie fazy Lavesa w mikrostrukturze stali PB2 po 50000 godzin starzenia: a) ciemne pole; b) rozwiązany dyfraktogram

chromium nitride $\mathrm{Cr}(\mathrm{V}, \mathrm{Nb}) \mathrm{N}$ - phase $\mathrm{Z}$. Laves phase precipitates in the examined steels after ageing were mainly observed on grain boundaries of former austenite usually near the $\mathrm{M}_{23} \mathrm{C}_{6}$ carbides and along grain boundaries.

The appearance of Laves phase precipitates in the microstructure of steel $9 \% \mathrm{Cr}$ during ageing/use is a very unfavourable phenomenon and is considered to be the main mechanism of degradation of this grade of steels $[5,13]$. Laves phase precipitates are observed in 9\% $\mathrm{Cr}$ steels already after approx. 500 hours of creeping $[13,14]$. In the initial period, Laves phase precipitates, due to their small size, influence the increase in precipitation strengthening. The low thermodynamic stability of the Laves phase results in a rapid increase in its size. This leads not only to a decrease in the precipitation strengthening, but also to a decrease in the solution strengthening of the matrix. The depletion of the matrix from substitute elements, which are also the components of $\mathrm{M}_{23} \mathrm{C}_{6}$ carbides, has a positive effect on the slowdown of the coagulation process of these precipitates [15].

$\mathrm{M}_{23} \mathrm{C}_{6}$ particles and Laves phases precipitated along grain boundaries also contribute to the reduction in ductility and increase of the temperature of the steel's transition into brittle state [21. The measurement showed that the average diameter of Laves phase precipitates in steel P91 was approx. $1135 \mathrm{~nm}(1.135 \mu \mathrm{m})$, while in steel PB2 it was approx. twice as low and amounted to $642 \mathrm{~nm}(0.642 \mu \mathrm{m})$. The smaller size of Laves phase precipitates in steel PB2 after ageing indicates the positive effect of the boron micro-addition on the increase in the stability of these precipitates.

In the P91 steel, single Z-phase precipitates, i.e. complex $\mathrm{Cr}(\mathrm{V}, \mathrm{Nb}) \mathrm{N}$ nitride, were observed, whereas these precipitates were not observed in the PB2 steel. The appearance of phase $\mathrm{Z}$ precipitates in the microstructure is related to the dissolution of fine-dispersed MX precipitates in the matrix. It is assumed that each large precipitate of the $\mathrm{Z}$ phase arises as a result of the disappearance of approx. 1,500 finely dispersed MX particles [16, 17]. The decrease in the density of MX precipitates leads to an increase in the distance between them, which negatively affects the creep strength of steel. The tendency to precipitate this unfavourable phase increases with the increase of chromium and niobium content in steel [16]. In $9 \% \mathrm{Cr}$ steels phase $\mathrm{Z}$ is a coherent precipitate, with a size comparable to MX precipitates and occurs in the microstructure usually in the form of single particles [16, 17], hence its influence on the properties of theses steels is relatively limited [18]. However, the inhibiting effect of MX precipitates on the dislocation movement was still observed in the tested steel.

\section{SUMMARY}

Two types of steel were tested - steel P91 (without boron micro-addition) and the experimental PB2 steel (with boron micro-additive). The analysed steels were subjected to longterm ageing for 50,000 hours at $620^{\circ} \mathrm{C}$. The conducted microscopic studies with computer image analysis showed that the boron micro-additive in steel PB2, compared to steel P91, slowed down the growth of the size of $\mathrm{M}_{23} \mathrm{C}_{6}$ and Laves phase precipitates, which translated into a delay in recovery processes and polygonisation of the matrix. In both analysed steels, finely-dispersed MX precipitates were stable during long-term ageing. In addition, single $\mathrm{Z}$ phase precipitates were observed in steel P91. 


\section{REFERENCES}

[1] R. Mishnev, N. Dudova, A. Fedoseeva, R. Kaibyshev. Microstructural aspect of superior creep resistance of a $10 \% \mathrm{Cr}$ martensitic steel. Materials Science and Engineering: A, 2016, 678, p. 178-189.

[2] C.G. Panait, W. Bendick, A. Fuchsmann, A.F. Gourgues-Lorenzon, J. Besson. Study of the microstructure of the Grade 91 steel after more than $100,000 \mathrm{~h}$ of creep exposure at $600^{\circ} \mathrm{C}$. Int. J. of Pressure Vessels and Piping, 2010, 87 (6), p. 326-335.

[3] H. Wang, W. Yan, S. Zwaag, Q. Shi, W. Wang, K. Yang, Y. Shan. On the $650^{\circ} \mathrm{C}$ thermostability of $9-12 \mathrm{Cr}$ heat resistant steels containing different precipitates. Acta Materialia, 2017, 134, p. 143-154.

[4] W. Zhong, W. Wang, X. Yang, W. Li, W. Yan, W. Sha, W. Wang, Y. Shan, K. Yang. Relationship between Laves phase and impact brittleness of P91 steel reevaluated. Materials Science and Engineering: A, 2015, 639, p. 252-258.

[5] M. Yoshizawa, M. Igarashi, K. Moriguchi, A. Iseda, H.G. Armaki, K. Maruyama. Effect of precipitates on long-term creep deformation properties of P92 and P122 type advanced ferritic steels for USC power plants. Materials Science and Engineering A, 2009, 510-511, p. 162-168.

[6] A. Kostka, K.G. Tak, R.J. Hellmig, Y. Estrin, G. Eggeler. On the contribution of carbides and micrograin boundaries to the creep strength of tempered martensite ferritic steels. Acta Materialia, 2007, 55 (2), p. 539-550.

[7] M. Hättestrand, H.O. Andrén. Boron distribution in 9-12\% chromium steels. Materials Science and Engineering: A, 1999, 270, p. $33-37$.

[8] J.G. Zhang, F.W. Noble, B.L. Eyre. Comparison of effects of aging on fracture of $9 \mathrm{Cr}-1 \mathrm{Mo}$ and $2 \cdot 25 \mathrm{Cr}-1 \mathrm{Mo}$ steel Part 1 Quenched and tempered material, Materials Science and Technology, 1991, 7 (3), p. $218-223$

[9] H.G. Armaki, R.P. Chen, K. Maruyam, M. Yoshizawa, M. Igarashi. Static recovery of tempered lath martensite microstructures during long-term aging in 9-12\% $\mathrm{Cr}$ heat resistant steels. Materials Letters, 2009, 63 (28), p. 2423-2425.
[10]G. Golański. Effect of the heat treatment on the structure and properties of GX12CrMoVNbN9-1 cast steel. Archives of Materials Science and Engineering, 2010, 46 (2), p. 88-97.

[11] F. Abe. Coarsening behavior of lath and its effect on creep rates in tempered martensitic $9 \mathrm{Cr}-\mathrm{W}$ steels. Materials Science and Engineering: $A$, 2004, 387-389, p. 565-569.

[12] F. Abe. New martensitic steels. In: A. Di Gianfrancesco, Materials for Ultra-Supercritical and Advanced Ultra-Supercritical Power Plants, series: Woodhead Publishing in energy, no. 104. Duxford, UK, Cambridge, MA: Woodhead Publishing 2017, p. 323-374.

[13] J.S. Lee, H.G. Armaki, K. Maruyama, T. Muraki, H. Asahi. Causes of breakdown of creep strength in $9 \mathrm{Cr}-1.8 \mathrm{~W}-0.5 \mathrm{Mo}-\mathrm{VNb}$ steel. Materials Science and Engineering: A, 2006, 428 (1-2), p. 270-275.

[14] X. Guo, J. Gong, Y. Jiang, D. Rong. The influence of long-term aging on microstructures and static mechanical properties of P92 steel at room temperature. Materials Science and Engineering: A, 2013, 564, p. 199-205.

[15] G. Golański, A. Zielińska-Lipiec, S. Mroziński, C. Kolan. Microstructural evolution of aged heat-resistant cast steel following strain controlled fatigue. Materials Science and Engineering: A, 2015, 627, p. 106-110.

[16] H.K. Danielsen, J. Hald. Infuence of Z-phase on long-term creep stability of martensitic 9 to $12 \%$ Cr steels. VGB PowerTech Journal, 2009, (5), p. 68-73.

[17] H.K. Danielsen, J. Hald. Behaviour of Z phase in 9-12\% Cr steels. Energy Materials Materials Science and Engineering for Energy Systems, 2006, 1 (1), p. 49-57.

[18] G. Golański, A. Zielińska-Lipiec, A. Zieliński, M. Sroka. Effect of long-term service on microstructure and mechanical properties of martensitic 9\% Cr steel. J. of Materials Engineering and Performance, 2017, 26 (3), p. 1101-1107. 